\title{
Benefits of Incorporating Induction Furnace Slag in Concrete as Replacement of Cement: A Case Study of Pakistan
}

\author{
MOHAMMAD LAEEQUE AHMED*, MUHAMMAD AFZAL JAVED*, AND ABDUL SAMI QURESHI**
}

RECEIVED ON 14.03.2018 ACCEPTED ON 25.05.2018

\begin{abstract}
As Pakistan along with the rest of the world continues to develop, demand for limited natural resources continues to increase also. This demand for resources and subsequent waste that is generated has driven the idea of sustainability towards the forefront of modern day research. To achieve this goal, new and innovative ways are being developed to recycle waste materials that otherwise would end up in landfill sites. Slag, a by-product of steel manufacturing is one such waste material. Pakistan as being a developing country does not have proper facilities to insure safe disposal and recycling of slag. Hence, new and innovative ways for recycling slag are a necessity for Pakistan to move towards technological advancement. Current study focuses to explore the feasibility of using local induction furnace slag as partial substitute of OPC (Ordinary Portland Cement) in concrete as well as to check its performance against chloride and sulphate damage. The test results showed that $15 \%$ or more slag replacement will make the concrete immune to chloride and sulphate damage. However, results also indicate that with increase in slag replacement percentage there is a significant drop in compressive, flexural and split tensile strength of concrete. Keeping in view the loss of strength, immunity against chloride and sulphate damage, reduction in cost of making concrete and sustainability benefits; $15 \%$ slag replacement has been deemed optimum replacement value.
\end{abstract}

Key Words: Local Induction Furnace Slag, Sustainability, Recycle Waste Materials, Chloride and Sulphate Damage.

\section{INTRODUCTION}

$\mathrm{R}$ apid population growth and depleting natural resources have brought the idea of sustainability in forefront of modern day research. Hence constant efforts are being made to introduce and improve sustainability in construction sector. To achieve this aim, the study of concrete has garnered focus of many researchers owing to its versatility and wide use as construction material.
Recently, attempts have been made to utilise refuse materials such as fly ash [1], silica fume [2] and recycled plastic fibre [3] etc. in concrete. The potential application of these industrial by-products as partial cement or aggregate replacement in concrete depends on their mechanical and chemical properties. Their utilization in concrete also comes from an environmental constraint i.e. safe disposal.

Authors Email: (laeeque.ahmad@ce.uol.edu.pk, mafzal.javed@ce.uol.edu.pk, sami.qureshi@faculty.muet.edu.pk)

* Department of Civil Engineering, The University of Lahore, Lahore.

** Department of Civil Engineering, Mehran University of Engineering \& Technology, Jamshoro.

This is an open access article published by Mehran University Research Journal of Engineering and Technology, Jamshoro under the CC by 4.0 International License. 
Steel slag is one such industry by-product, produced during steel smelting process. Roughly 0.2 ton of slag is generated when 1 ton of crude steel is produced [4]. Pakistan produced 2.89 million metric tons of crude steel [5] corresponding to 0.58 million tons of steel slag being generated. This huge quantity of slag generated each year is discarded as trash and put in landfills. That's why solid waste management of steel slag is one of the major environmental concerns for underdeveloped countries like Pakistan.

Steel industry of Pakistan can be split into two categories, public (government owned) and private sector. Pakistan Steel is the only pubic enterprise operational right now. It contains 2 blast furnace units with a production capacity of 1.1 million tons per annum of crude steel [6]. As byproduct it produces granulated blast furnace slag. Remaining steel demand of the country is met by private sector. Private sector comprises of small scale 140 steel melting induction furnaces [7], which are spread throughout the different regions of Pakistan. Chemical composition of slag produced in these induction furnaces greatly vary from blast furnace slag.

Majority of previous researches related to using slag in concrete have been focused on incorporating blast furnace slag rather than induction furnace slag. GGBS
(Ground Granulated Blast Furnace Slag) have been extensively used as fine aggregate replacement [8], coarse aggregate replacement [9] and also as partial cement replacement [10] in concrete. Other aspects of GGBS concrete like sustainability [11] as well as performance against creep and shrinkage [12] have already been evaluated also. Whereas incorporation of induction furnace slag in concrete have been mostly confined to aggregate replacement [13]. Attempts for cement replacement with induction furnaces slag have been very limited. This is due to the fact that induction furnace slag contains higher levels of iron oxide and lower levels of silica in comparison to GGBS. These factors reduce its potential of being used as cement replacement material in concrete as compared to GGBS. Therefore, current study aims to identify the benefits of partially replacing OPC content by locally available induction furnace slag in concrete.

\section{MATERIALS USED}

\subsection{Cement}

ASTM Type-I OPC [14] cement was used throughout the study. Basic properties of the selected cement were determined using ASTM standard procedures [14-15]. Outcome of these tests are mentioned in Table 1.

TABLE 1. OPC PROPERTIES

\begin{tabular}{|c|c|c|}
\hline Properties & Lab Test Values & Manufacturer Values \\
\hline Specific Gravity & 3.02 & $<10 \%$ \\
\hline Fineness & $4.4 \%$ & $>30 \mathrm{~min}$ \\
\hline Initial Setting Time & $43 \mathrm{~min}$ & $<600 \mathrm{~min}$ \\
\hline Final Setting Time & $270 \mathrm{~min}$ & - \\
\hline Normal Consistency & $33 \%$ & $28 \mathrm{~N} / \mathrm{mm}$ \\
\hline & Compressive Strength of Cement: sand $(1: 3)$ Mortar & $42 \mathrm{~N} / \mathrm{mm}$ \\
\hline 3-Days & $25.3 \mathrm{~N} / \mathrm{mm}$ & $54 \mathrm{~N} / \mathrm{mm}$ \\
\hline 7-Days & $36.7 \mathrm{~N} / \mathrm{mm}$ & \multicolumn{2}{|c|}{} \\
\hline 28-Days & $52.4 \mathrm{~N} / \mathrm{mm}$ & \\
\hline
\end{tabular}

Mehran University Research Journal of Engineering \& Technology, Volume 37, No. 4, October, 2018 [p-ISSN: 0254-7821, e-ISSN: 2413-7219] 


\section{$2.2 \quad$ Aggregates}

Local quarried fine and coarse aggregates were used in the study. Their material properties were determined using ASTM standard procedure [16]. Details of fine and coarse aggregate properties are shown in Tables 2-3 respectively.

\subsection{Steel Slag}

Induction furnace slag was collected from a local steel mill located in Lahore. Slag Samples collected from the industry land filling site were gridded to 44 micron size (Sieve \# 325 passing) as per the ASTM standard [17]. Then the powdered slag was (dry) mixed with cement as partial replacement of binder. The steel slag collection and grinding process is detailed in Fig. 1.

The replacement percentages were kept $0,5,10,15$ and $20 \%$ by weight respectively. Chemical Analysis was conducted in reference to the techniques mentioned in ASTM C 323. Chemical composition of selected steel slag sample and blast furnace slag from 'Pakistan Steel' are mentioned in Tables 4- 5 [18].

The results shown in Table 4 indicate that steel slag still contain high quantity of Hematite $\left(\mathrm{Fe}_{2} \mathrm{O}_{3}\right)$. Lack of quality

TABLE 2. PROPERTIES OF FINE AGGREGATES

\begin{tabular}{|c|c|}
\hline Property & Value \\
\hline Type & Natural \\
\hline Fineness Modulus & 2.4 \\
\hline Specific Gravity & 2.69 \\
\hline Total Water Absorption & $1.03 \%$ \\
\hline
\end{tabular}

TABLE 3. PROPERTIES OF COARSE AGGREGATES

\begin{tabular}{|c|c|}
\hline Property & Value \\
\hline Type & Natural (Crushed) \\
\hline Fineness Modulus & 7.4 \\
\hline Specific Gravity & 2.75 \\
\hline Total Water Absorption & $3.6 \%$ \\
\hline
\end{tabular}

control during smelting process is the main reason for such high quantity of ore being left un-reacted. Some lapses of quality control are documented in Figs. 2-5.

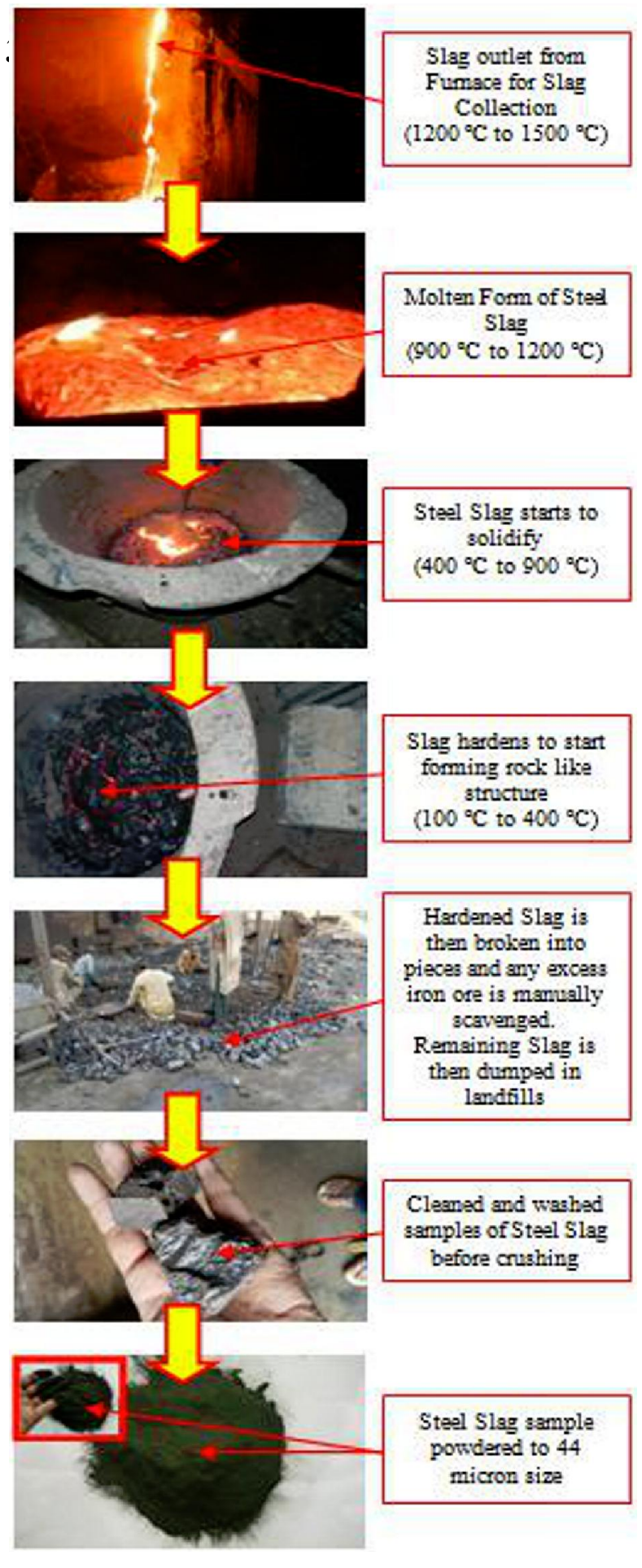

FIG. 1. STEEL SLAG COLLECTION AND GRINDING PROCESS

Mehran University Research Journal of Engineering \& Technology, Volume 37, No. 4, October, 2018 [p-ISSN: 0254-7821, e-ISSN: 2413-7219] 
Following the ACI Mix Design Standard [19] requirements for compressive strength of $28 \mathrm{MPa}$, a mix ratio of 1:1.5:3 (binder: fine aggregate: coarse aggregate) and water to binder ratio value of 0.5 was set for the concrete samples to be tested. The water-to-binder ratio $(w /(c+p))$ remained constant throughout entire testing stage using weight equivalency technique [19] as cement was replaced by weight with different $(0,5,10,15$ and $20 \%)$ percentages of steel slag.

TABLE 4. CHEMICAL ANALYSIS OF SELECTED SAMPLE

\begin{tabular}{|c|c|}
\hline Chemical Composition & Percentages (\%) \\
\hline Loss on Ignition & 0.08 \\
\hline Silica (SiO2) & 13.12 \\
\hline Alumina (A2O3) & 4.88 \\
\hline Iron Oxide (Fe2O3) & 37.54 \\
\hline Calcium Oxide $(\mathrm{CaO})$ & 39.50 \\
\hline Magnesium Oxide $(\mathrm{MgO})$ & 4.51 \\
\hline Sodium Oxide $(\mathrm{Na2O})$ & 0.32 \\
\hline Potassium Oxide $(\mathrm{K} 2 \mathrm{O})$ & 0.04 \\
\hline
\end{tabular}

TABLE 5. PAKISTAN STEEL'S BFS CHEMICAL ANALYSIS

\begin{tabular}{|c|c|}
\hline Chemical Composition & Percentages (\%) \\
\hline Calcium Oxide & $36-40 \%$ \\
\hline Silica (SiO2) & $36-39 \%$ \\
\hline Alumina (A12O3) & $14-16 \%$ \\
\hline Magnesium Oxide (MgO) & $9 \% \max$ \\
\hline Manganese Oxide & $1.3 \% \max$ \\
\hline Titanium Oxide & $0.881 \% \max$ \\
\hline Iron Oxide & $0.5 \% \max$ \\
\hline Sulphur & $1.5 \% \max$ \\
\hline
\end{tabular}

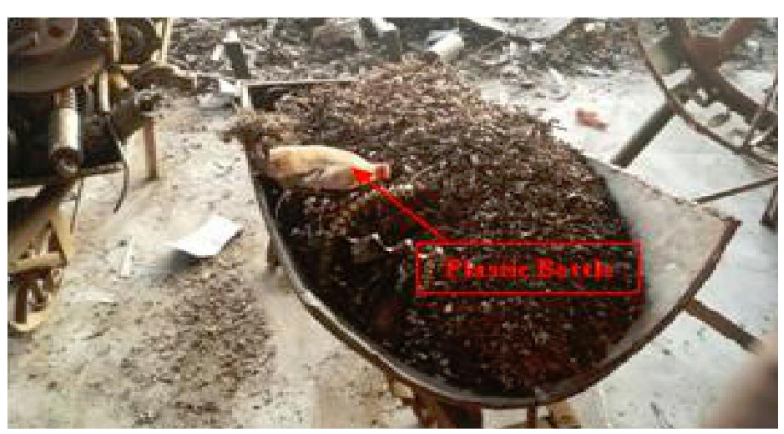

FIG. 2. NON-METALLIC ITEMS LEFT IN SCRAP METAL

\section{DIFFERENT CURING MEDIUMS FOR CONCRETE TESTING}

To better understand the sustainability and durability of concrete made with steel slag against chlorides and sulphate attacks. Test specimens were immersed and cured in three different curing mediums; namely water, chloride and sulphate medium. A study conducted by Jakhrani et. al. [20] on the seawater in the vicinity of Karachi harbour

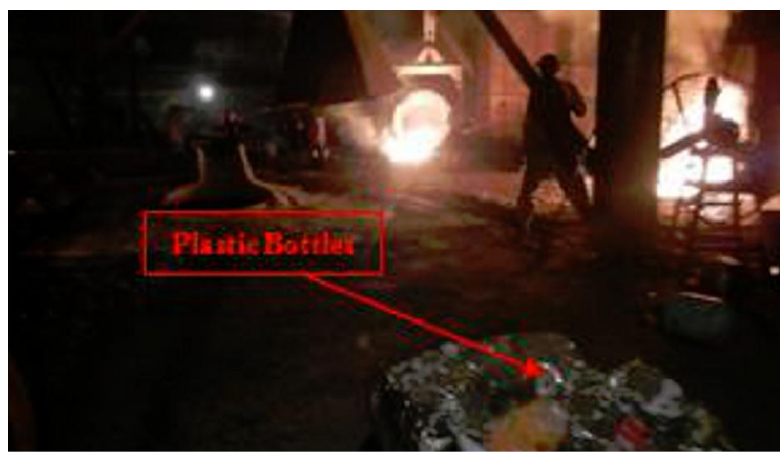

FIG. 3. PLASTIC BOTTLES BEING USED AS CHARGE

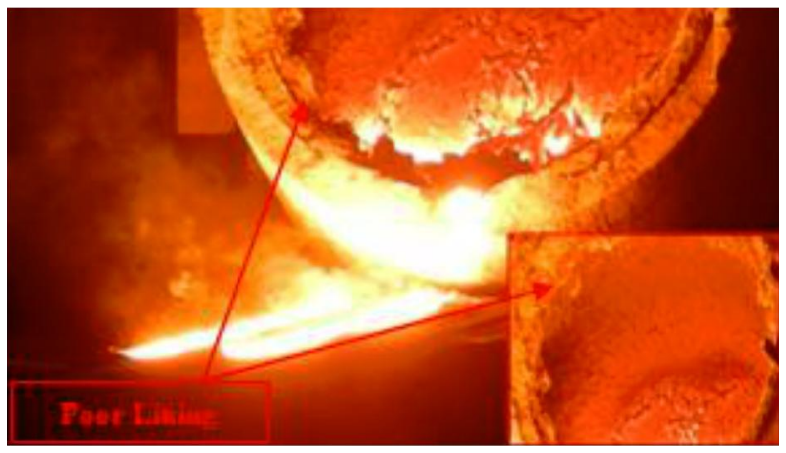

FIG. 4. POOR FURNACE LINING WORKMANSHIP
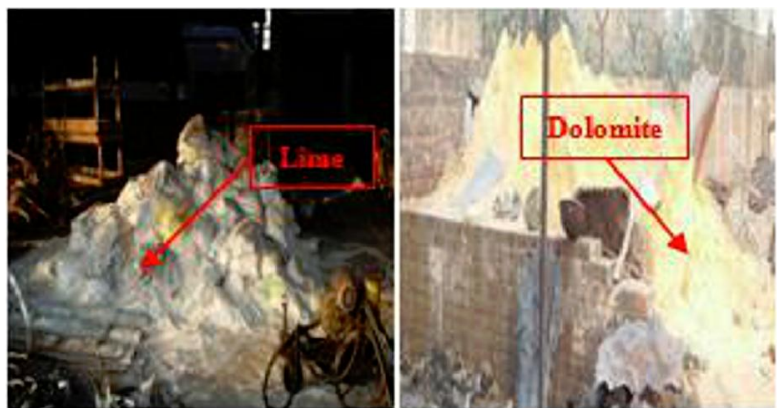

FIG. 5. FLUX MATERIALS ARE LEFT EXPOSED TO NATURE

Mehran University Research Journal of Engineering \& Technology, Volume 37, No. 4, October, 2018 [p-ISSN: 0254-7821, e-ISSN: 2413-7219] 
showed a maximum chloride concentration of $19800 \mathrm{ppm}$ or $19.8 \mathrm{~g} / \mathrm{L}$ and maximum sulphate concentration of 2949 ppm or $2.949 \mathrm{~g} / \mathrm{L}$ respectively.

Considering the above mentioned findings and the prospect that pollution will keep on increasing in future, current study is carried out by taking $22000 \mathrm{ppm}$ or $22 \mathrm{~g} /$ $\mathrm{L}$ of chloride concentration and $4000 \mathrm{ppm}$ or $4 \mathrm{~g} / \mathrm{L}$ of sulphate concentration for their respective curing mediums.

The curing guidelines mentioned in ASTM standard [21] were observed for all three mediums (water, chloride and sulphate). Water cured test specimens acted as control samples for test specimens cured in other two mediums (i.e. chloride and sulphate). Details of how each curing medium were prepared is mentioned as under:

Water Medium: Normal portable water having $\mathrm{pH}$ value from 6-8 was used. Fig. 6 shows cylinder and prism test specimens being cured in water medium.

Chloride Medium: 36.27 grams of sodium chloride $(\mathrm{NaCl})$ was dissolved per litre of water to form the aqueous curing medium with the desired chloride concentration of $22 \mathrm{~g} /$ L. Fig. 7 shows cylinder and prism test specimens being cured in chloride medium.
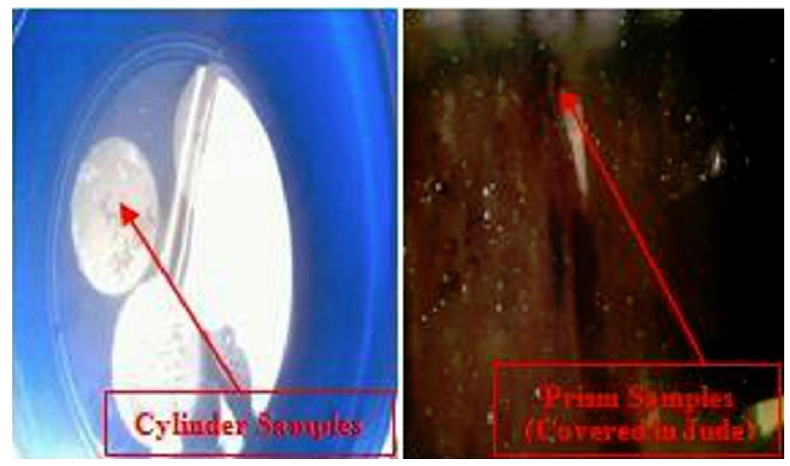

FIG. 6. TEST SPECIMENS CURED IN WATER MEDIUM
Sulphate Medium: 5.92 grams of sodium sulphate $\left(\mathrm{NaSO}_{4}\right)$ was dissolved per litre of water to form the aqueous curing medium with the desired sulphate concentration of $4 \mathrm{~g} / \mathrm{L}$. Fig. 8 shows cylinder and prism test specimens being cured in sulphate medium.

\section{BULK DRY DENSITY}

Bulk dry density of samples was found before they were tested for compression, flexure or splitting tensile strength. The volumes of a cylinder and a prism are 0.0053 and 0.0112 $\mathrm{m}^{3}$ respectively. To calculate the dry density of sample, each samples is first dried with a cloth (SSD Condition) and then weighed to the nearest 0.001 kilogram. Each sample is weighed and this weight is divided by the volume to find the bulk dry densities.

To insure accuracy of results, the bulk density of three samples of control concrete (having $0 \%$ slag) and three samples for each successive replacement of cement with

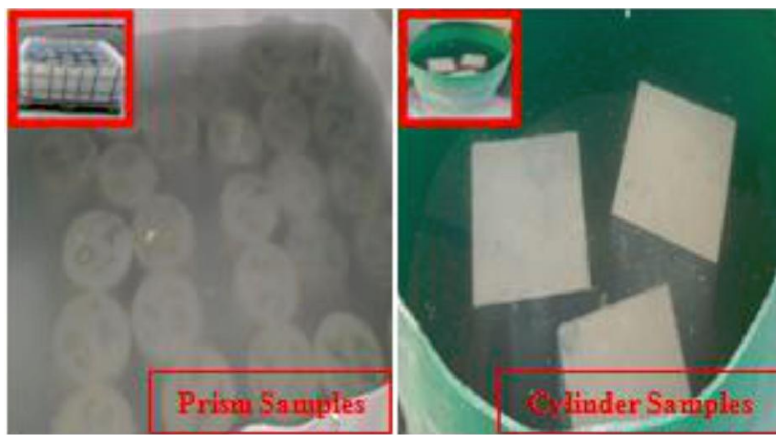

FIG. 7. TEST SPECIMENS CURED IN CHLORIDE MEDIUM

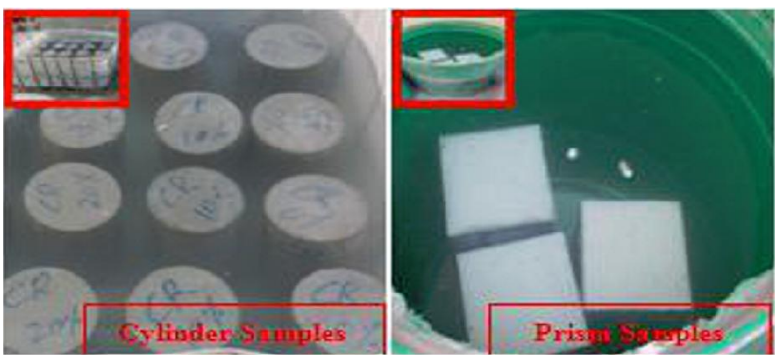

FIG. 8. TEST SPECIMENS CURED IN SULPHATE MEDIUM

Mehran University Research Journal of Engineering \& Technology, Volume 37, No. 4, October, 2018 [p-ISSN: 0254-7821, e-ISSN: 2413-7219] 
steel slag in concrete $(5,10,15$ and $20 \%)$ were evaluated.

Table 6 shows the results of bulk dry density tests against each percentage steel slag replacement of concrete.

Overall increase in dry density between control ( $0 \%$ slag) sample and $20 \%$ slag sample is just $1.73 \%$, which is very minute increase. The graphical representation of results in Fig. 9 shows this slight increasing trend from $0-20 \%$ slag samples. The trend indicates that each successive increase from $0-20 \%$ have very minutely increased the density of concrete.

\section{SLUMP TEST}

Slump is basically a measure of workability which is largely dependent of the value of water-cement ratio. If

TABLE 6. DRY DENSITY OF STEEL SLAG CONCRETE

\begin{tabular}{|c|c|}
\hline Slag Replacement (\%) & Dry Density $(\mathrm{Kg} / \mathrm{m} 3)$ \\
\hline 0 & 2392 \\
\hline 5 & 2401 \\
\hline 10 & 2409 \\
\hline 15 & 2432 \\
\hline 20 & 2434 \\
\hline
\end{tabular}

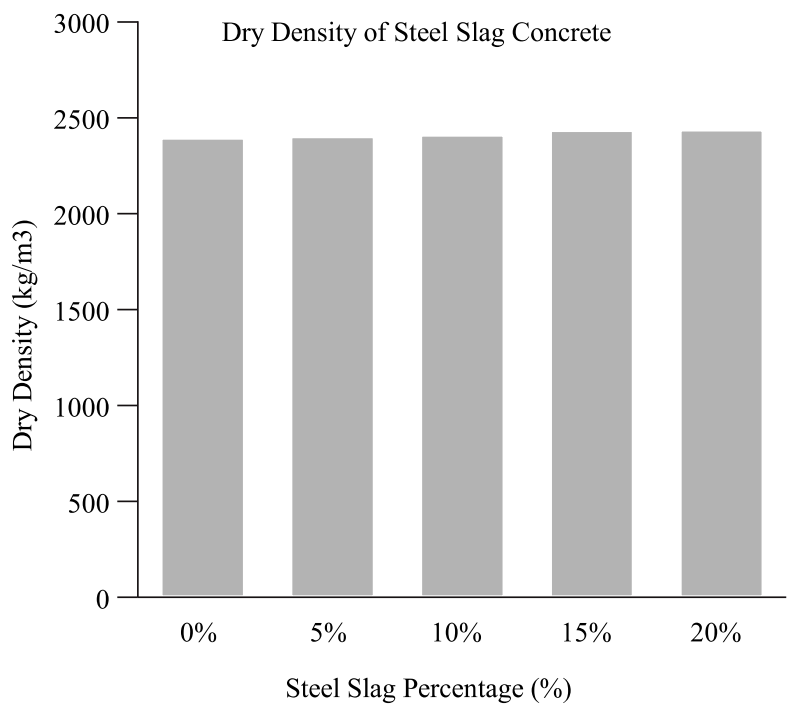

FIG. 9. GRAPH OF DRY DENSITY VS SLAG PERCENTAGE more free water is accessible at the time of batching then more will be the fall of slump. Review of previous researches [22-23] indicate that hydration of slag occur much slower than compared to OPC. Therefore, as the percentage of cement replacement with steel slag increases the fall of slump should also increase. This trend was also observed in results of current study as shown in Table 7. Test was conducted as per ASTM standards [24].

\section{COMPRESSIVE STRENGTH}

The compressive strength for different percentages $(0,5,10,15$ and $20 \%)$ of slag replaced concrete was measured after seven (7), fourteen (14) and twenty-eight (28) days. All the samples were tested using compressive strength testing machine (Fig. 10). The loading rate for testing was kept constant at $0.25 \pm 0.05 \mathrm{MPa} / \mathrm{s}$ [25]. To improve the accuracy of results, three cylinders of each slag replacement for every individual curing medium (water, chloride and sulphate) were casted and the average of these samples was taken. The concrete cylinders were cured in each curing medium at room temperature $\left(25^{\circ} \mathrm{C} \pm 5\right)$. Compressive strength variations of samples cured in water, chloride and sulphate mediums are shown in Fig. 11 for 7 day strengths, Fig. 12 for 14 day strengths and Fig.13 for 28 day strengths respectively.

TABLE 7. SLUMP FOR DIFFERENT SLAG REPLACEMENTS

\begin{tabular}{|c|c|}
\hline Slag Replacement (\%) & Slump Values (mm) \\
\hline 0 & 58 \\
\hline 5 & 65 \\
\hline 10 & 78 \\
\hline 15 & 89 \\
\hline 20 & 102 \\
\hline
\end{tabular}

Mehran University Research Journal of Engineering \& Technology, Volume 37, No. 4, October, 2018 [p-ISSN: 0254-7821, e-ISSN: 2413-7219] 
The results clearly indicate sharp decrease of compressive strength after $15 \%$ replacement of cement with slag. At 28 days, the reduction in strength for each $5 \%$ replacement of slag between 0 and $15 \%$ was up to 1.5 $\mathrm{MPa}$ while more than $2.5 \mathrm{MPa}$ decrease in

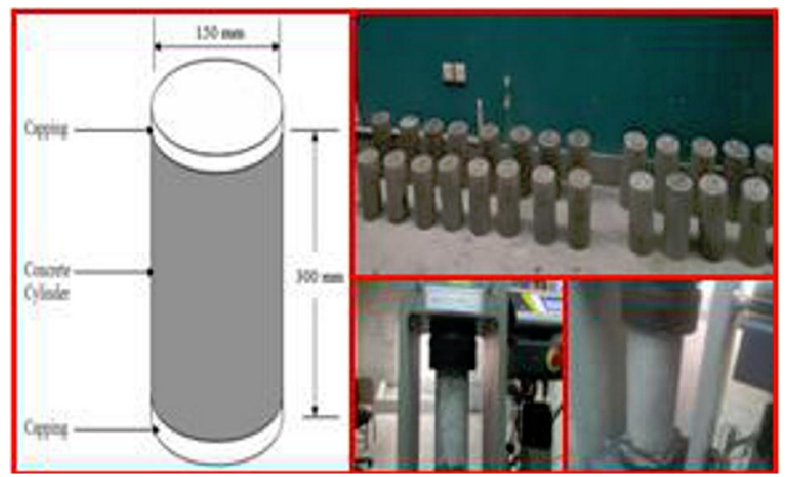

FIG. 10. CONCRETE CYLINDER COMPRESSIVE STRENGTH TEST

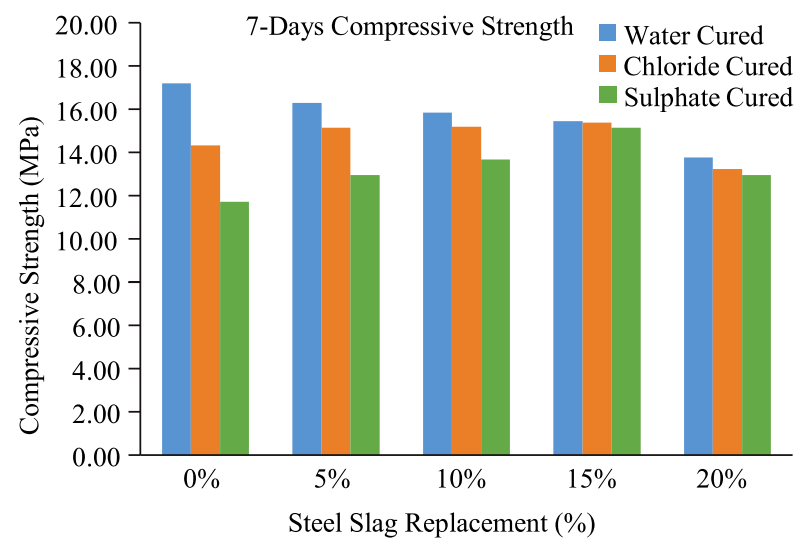

FIG. 11. COMPRESSIVE STRENGTH AT 7 DAYS

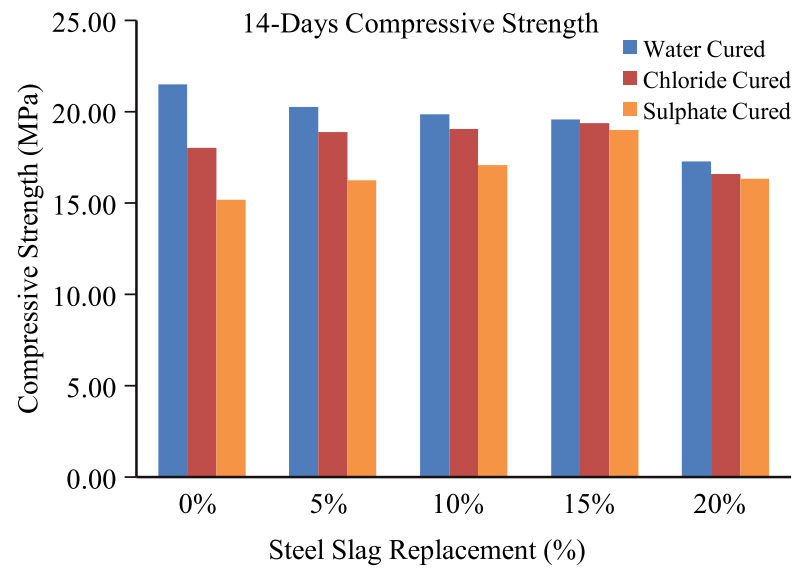

FIG. 12. COMPRESSIVE STRENGTH AT 14 DAYS compressive strength was observed in between $15-20 \%$ slag replacement. Same kind of trends was observed at 7 and 14 days as well. This reduction in compressive strength occurred due to the fact that normal OPC is composed almost $65 \%$ [14] of calcium oxide while the replacement slag only contained $39.50 \%$ (Table 4 ) calcium oxide, which is the essential for producing $\mathrm{C}_{3} \mathrm{~S}$ and $\mathrm{C}_{2} \mathrm{~S}$ binding compounds.

Another very important observation was that the results of 15 and $20 \%$ slag replacement yield almost identical strength in all curing mediums. This means that $15-20 \%$ steel slag replaced concrete will give almost same strength if cured in water, chloride or sulphate environment; greatly improving resistance of concrete against chloride and sulphate.

\section{FLEXURAL STRENGTH}

Flexural strength of different percentages $(0,5,10,15$ and $20 \%$ ) of slag replaced concrete was measured after 28 and 56-days. All the prism samples (150x150x500mm) were tested using three point loading machine as per the guidelines mentioned in ASTM standards [26], shown in Fig. 14. Loading rate for testing was kept at $1.0 \pm 0.05$ $\mathrm{MPa} / \mathrm{min}[26]$.

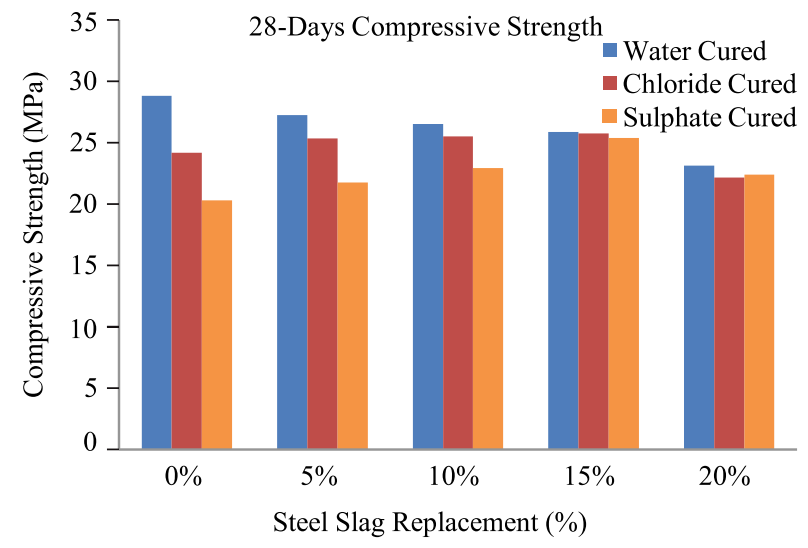

FIG. 13. COMPRESSIVE STRENGTH AT 28 DAYS 
To improve the accuracy of results, three prisms of each slag replacement for every individual curing medium (water, chloride and sulphate) were casted and the average of these samples was taken. The concrete prisms were cured in each curing medium at room temperature $\left(25^{\circ} \mathrm{C} \pm\right.$ 5). Flexural strength variations of samples cured in water, chloride and sulphate mediums are shown in Fig. 15 for 28-days strengths and Fig. 16 for 56 day strengths respectively.

Chloride medium cured prism showed highest flexural strength with 10 and $15 \%$ slag replacement at 28 and 56 days respectively. Sulphate medium cured prisms however indicated maximum flexural strength with $15 \%$ slag replacement on both 28 and 56 days testing.

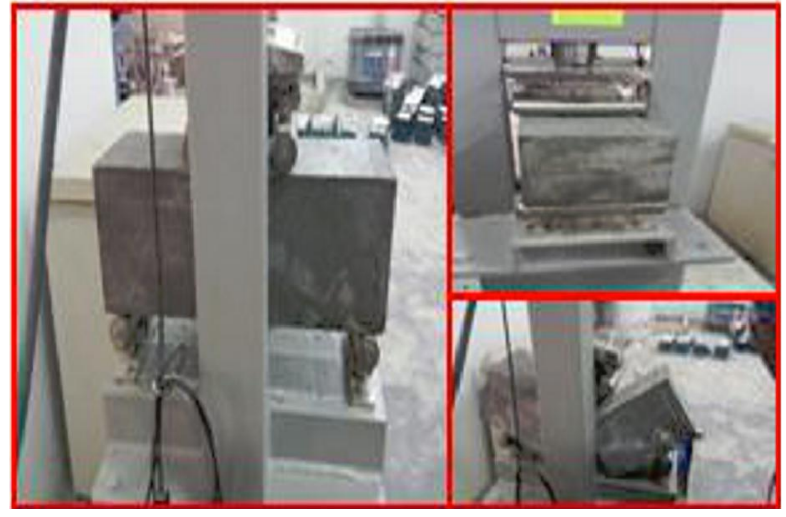

FIG. 14. FLEXURAL STRENGTH TEST OF CONCRETE PRISMS

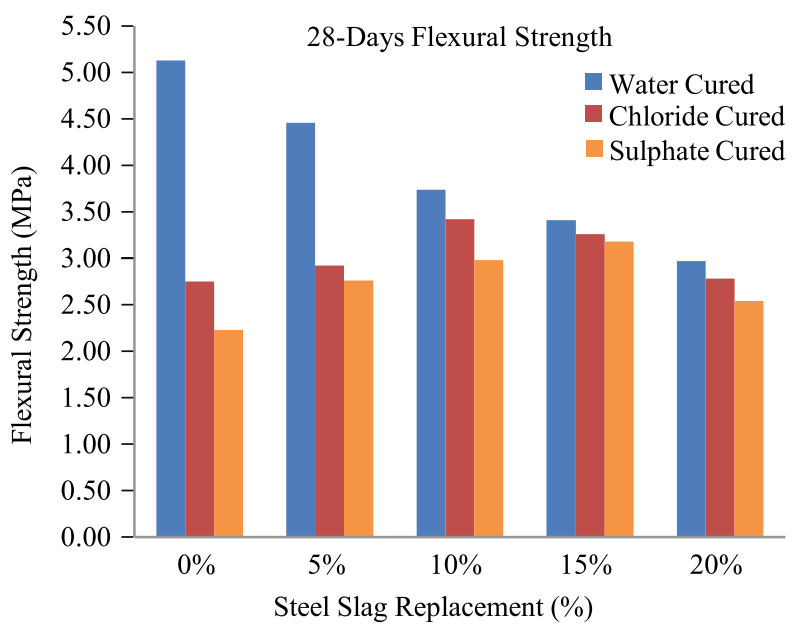

FIG. 15. FLEXURAL STRENGTH AT 28 DAYS
The results also indicate sharp decrease (up to $2.9 \mathrm{MPa}$ on 28-days and up to $2.75 \mathrm{MPa}$ on 56-days) in flexural strength of 0 and $5 \%$ slag replacement samples in chloride and sulphate curing medium as compared to water curing medium. The results of 15 and $20 \%$ slag replacement samples are almost the same in all curing mediums. Another important observation was that at 56 days testing; prisms cured in sulphate medium show higher strength than the prism cured in chloride. This indicates slightly improved resistance of slag concrete against sulphate in comparison to chloride in the long run.

\section{SPLITTING TENSILE STRENGTH}

Since modulus of rupture discussed in section 8 is an indirect evaluation of tensile capabilities of the concrete. So splitting tensile strength of cylinder being more direct approach to determine tensile strength of concrete as specified by ASTM standard [27] was also performed. The splitting tensile strength of different percentages $(0,5,10,15$ and $20 \%)$ of steel slag replaced concrete was measured after twenty-eight (28) and fifty-six (56) days. All the cylinder samples $(150 \mathrm{~mm}$ diameter and $300 \mathrm{~mm}$ length) were tested using UTM (Universal Testing Machine) as shown in Fig. 17. And

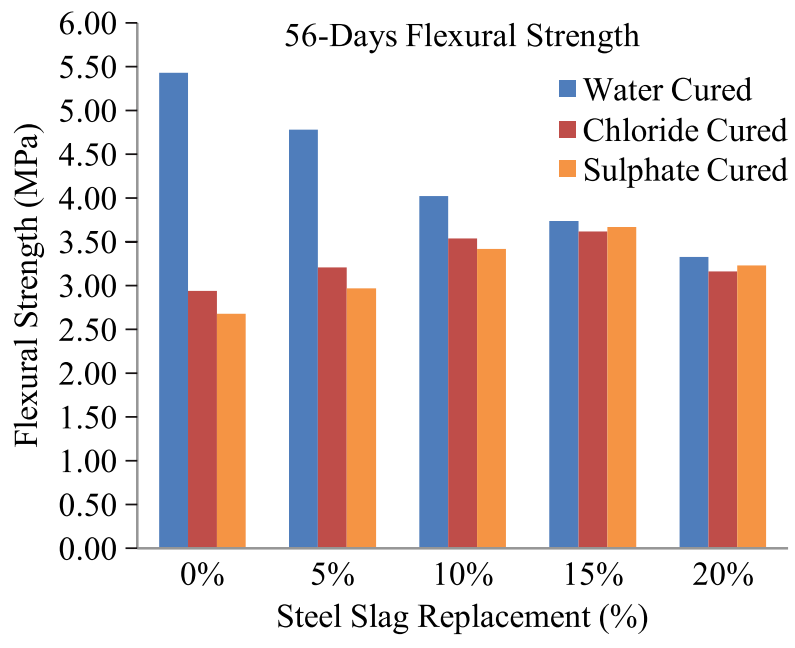

FIG. 16. FLEXURAL STRENGTH AT 56 DAYS 
loading rate during the testing was kept constant at $1.0 \pm 0.05 \mathrm{MPa} / \mathrm{min}[28]$.

To improve the accuracy of results, three cylinders of each slag replacement for every individual curing medium (water, chloride and sulphate) were casted and the average of these samples was taken. The concrete cylinders were cured in each curing medium at room temperature $\left(25^{\circ} \mathrm{C} \pm\right.$ $5)$. The variations in splitting tensile strength of samples cured in water, chloride and sulphate mediums are shown in Fig. 18 for 28 day strengths and Fig. 19 for 56 day strengths respectively.

The results of 56 days testing of 15 and $20 \%$ slag replacement samples have almost become identical.

This is due to the fact that slag takes longer time to

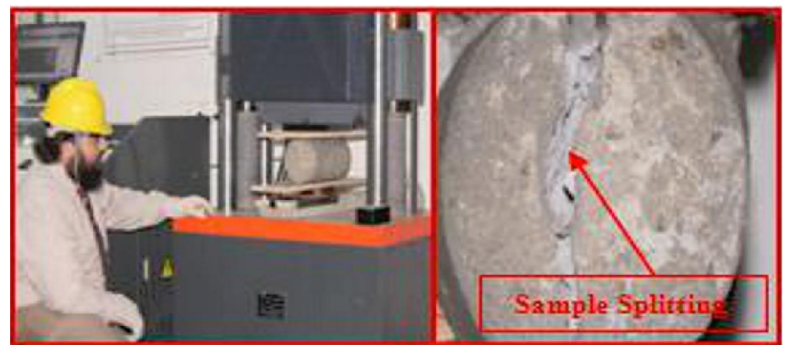

FIG. 17. SPLITTING TENSILE TEST ON CONCRETE CYLINDER

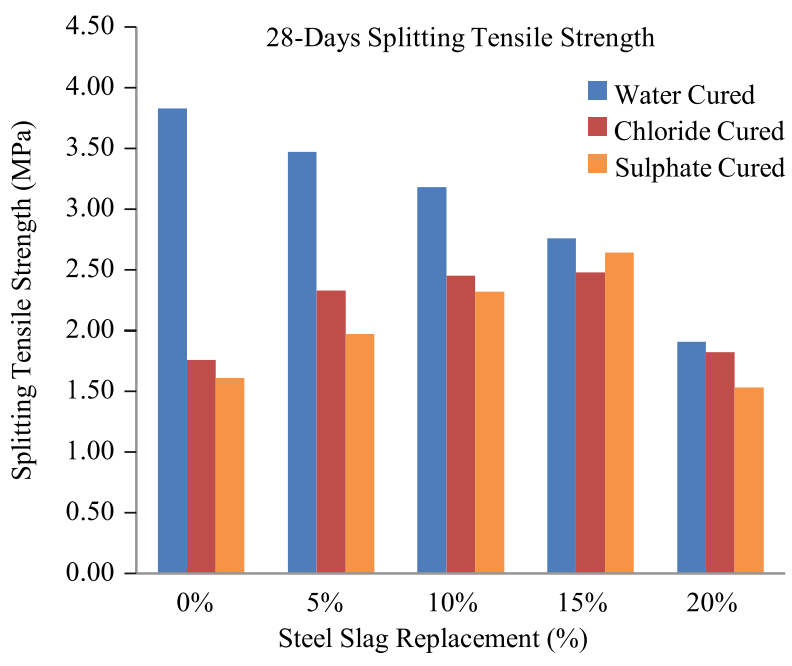

FIG. 18. SPLITTING TENSILE STRENGTH AT 28 DAYS hydrate as compared to OPC [27]. The delay in hydration and lack of calcining agent cause the reduction of splitting tensile strength but also provide longer duration of protection against chloride and sulphate damage.

\section{COST ANALYSIS}

To understand the cost savings, it is essential to calculate the material quantities based on the mix ratio $(1: 1.5: 3)$ used during the experimentation of this research. The calculations done for cost analysis are mentioned as under:

(i) Bulk densities of cement (binder) $=1440 \mathrm{~kg} / \mathrm{m}^{3}$, sand (fine aggregate) $=1770 \mathrm{~kg} / \mathrm{m}^{3}$ and crush (course aggregate) $=1680 \mathrm{~kg} / \mathrm{m}^{3}$ respectively.

(ii) Specific gravities of cement $=3.02$, sand $=2.69$ and crush $=2.75$ respectively.

(iii) Percentage of air entrained is $2.5 \%$.

(iv) The mix proportioning of 1:1.5:3 of materials by dry volume can be expressed in terms of masses as:

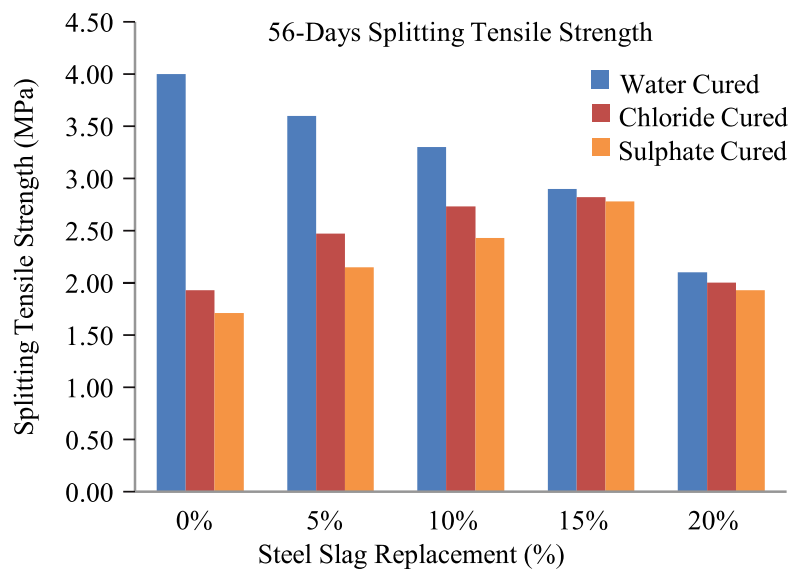

FIG. 19. SPLITTING TENSILE STRENGTH AT 56 DAYS 


$$
\begin{array}{r}
\mathrm{OPC}=1 \times 1440=1440 \mathrm{~kg} \\
\text { Sand }=1.5 \times 1770=2655 \mathrm{~kg} \\
\text { Crush }=3 \times 1680=5040 \mathrm{~kg}
\end{array}
$$

Therefore, ratio of masses of these materials with respect to OPC will be,

$1: \frac{2655}{1440}: \frac{5040}{1440}=1: 1.8: 3.5$

The water-to-binder ratio $=0.5$

(v) Using Absolute Volume Method to calculate the amount of concrete produced by one bag of cement (i.e. $50 \mathrm{~kg}$ cement).

$\mathrm{V}_{\mathrm{c}}=\frac{0.5 \times 50}{1000}+\frac{1 \times 50}{1000 \times 3.02}+\frac{1.8 \times 50}{1000 \times 2.69}+\frac{3.5 \times 50}{1000 \times 2.75}=0.13865 \mathrm{~m}^{3}$

So one bag of cement $(50 \mathrm{~kg})$ will produce $0.13865 \mathrm{~m}^{3}$ of concrete

(vi) Since entrained air is considered to be $2.5 \%$, so actual volume of concrete for $1 \mathrm{~m}^{3}$ of compacted concrete construction will be equal to $1-0.025=$ $0.975 \mathrm{~m}^{3}$.

(vii) The quantity of cement required for 1 cubic metre of concrete mix is equal to $0.975 / 0.13865=7.03$ bags of cement.

(viii) Therefore, quantities of materials for $1 \mathrm{~m}^{3}$ of concrete are:

$$
\begin{aligned}
& \text { Cement }=7.03 \times 50=351.5 \mathrm{~kg} \\
& \text { Sand }=1.5 \times 351.5=527.25 \mathrm{~kg} \\
& \text { Crush }=3 \times 351.5=1054.5 \mathrm{~kg}
\end{aligned}
$$

As per the ACI Mix Design Standard the slag replacement was done using weight equivalency. For example, in a $15 \%$ slag replacement sample an absolute $15 \%$ weight of cement is being replaced by steel slag.

(ix) The weight of cement replaced by samples containing $5,10,15$ and $20 \%$ slag for $1 \mathrm{~m}^{3}$ of concrete will become,

$$
\begin{aligned}
& 5 \% \text { Slag Sample }=0.05 \times 351.5=17.575 \mathrm{~kg} \\
& 10 \% \text { Slag Sample }=0.10 \times 351.5=35.150 \mathrm{~kg} \\
& 15 \% \text { Slag Sample }=0.15 \times 351.5=52.725 \mathrm{~kg} \\
& 20 \% \text { Slag Sample }=0.20 \times 351.5=70.300 \mathrm{~kg}
\end{aligned}
$$

After the material calculations the next step was to determine the cost of cement. For this study, DG Cement (ASTM Type I) has been used which cost 535 PKR per bag and 10.7 PKR per kg respectively (At the time of writing this paper). So cost of cement for each cubic metre of $1: 1.5: 3 \mathrm{mix}$ is $351.5 \times 10.7=3761 \mathrm{PKR}$.

(x) Therefore, cost savings of producing $1 \mathrm{~m}^{3}$ concrete with $5,10,15$ and $20 \%$ replacement respectively will be,

$$
\begin{aligned}
& 5 \% \text { Slag Sample }=17.575 \times 10.7=188.052 \mathrm{PKR} \\
& 10 \% \text { Slag Sample }=35.150 \times 10.7=376.105 \mathrm{PKR} \\
& 15 \% \text { Slag Sample }=52.725 \times 10.7=564.158 \mathrm{PKR} \\
& 20 \% \text { Slag Sample }=70.300 \times 10.7=752.210 \mathrm{PKR}
\end{aligned}
$$

(xi) Cost of Grinding, Transportation and other miscellaneous expenditure per $\mathrm{kg}$ of Slag are estimated to be PKR 1.15

(xii) Total cost savings for $1 \mathrm{~m}^{3}$ concrete mix containing 5, 10, 15 and $20 \%$ replacement respectively are: 


$$
\begin{aligned}
& 5 \% \text { Slag }=188.052-(17.575 \times 1.15) \approx 167 \text { PKR } \\
& 10 \% \text { Slag }=376.105-(35.150 \times 1.15) \approx 335 \text { PKR } \\
& 15 \% \text { Slag }=564.158-(52.725 \times 1.15) \approx 503 \text { PKR } \\
& 20 \% \text { Slag }=725.210-(70.300 \times 1.15) \approx 644 \text { PKR }
\end{aligned}
$$

(xiii) Total cost reduction for $1 \mathrm{~m}^{3}$ concrete mix containing 5,10,15 and 20\% replacement respectively are:

$$
\begin{gathered}
5 \% \text { Slag }=100-[\{(3761-167) / 3761\} \times 100] \approx 4.4 \% \\
10 \% \text { Slag }=100-[\{(3761-335) / 3761 \times 100] \approx 8.9 \% \\
15 \% \text { Slag }=100-[\{(3761-503) / 3761\} \times 100] \approx 13.4 \% \\
20 \% \text { Slag }=100-[\{(3761-644) / 3761\} \times 100] \approx 17.1 \%
\end{gathered}
$$

\section{SUSTAINABILITY ANALYSIS}

Ernst Worrell et al. [29] estimated that about 1 tonne of $\mathrm{CO}_{2}$ and other GHG (Green House Gases) are produced on manufacturing each tonne of OPC. Considering these estimates, the calculation of $\mathrm{CO}_{2}$ emissions are:

(i) Each metre cube of 1:1.5:3 concrete mix contains $351.5 \mathrm{~kg}$ OPC

(ii) Using Weight Equivalency per slag replacement is:

$5 \%$ slag $=17.575 \mathrm{~kg}$ Slag per $1 \mathrm{~m}^{3}$ of concrete mix $10 \%$ slag $=35.150 \mathrm{~kg}$ Slag per $1 \mathrm{~m}^{3}$ of concrete mix $15 \%$ slag $=52.725 \mathrm{~kg}$ Slag per $1 \mathrm{~m}^{3}$ of concrete mix $20 \%$ slag $=70.300 \mathrm{~kg}$ Slag per $1 \mathrm{~m}^{3}$ of concrete mix

(iii) Since for every $1000 \mathrm{~kg}$ OPC manufacture 1000 $\mathrm{kg}$ of $\mathrm{CO}_{2}$ is produced.

(iv) Therefore, reduction of $\mathrm{CO}_{2}$ emission per $1 \mathrm{~m}^{3}$ of concrete mix will be,
$5 \%$ slag replacement $=17.575 / 1000=0.0177$ tonne

$10 \%$ slag replacement $=35.150 / 1000=0.0351$ tonne

$15 \%$ slag replacement $=52.7251000=0.0527$ tonne

$20 \%$ slag replacement $=70.300 / 1000=0.0703$ tonne

(v) And percentage reduction of $\mathrm{CO}_{2}$ emission per $1 \mathrm{~m}^{3}$ of concrete mix will be,

$$
\begin{aligned}
& 5 \% \text { slag replacement }=0.0177 \times 100=1.77 \% \\
& 10 \% \text { slag replacement }=0.0351 \times 100=3.51 \% \\
& 15 \% \text { slag replacement }=0.0527 \times 100=5.27 \% \\
& 20 \% \text { slag replacement }=0.0703 \times 100=7.03 \%
\end{aligned}
$$

\section{CONCLUSIONS}

Following are the conclusions drawn from experimental results:

(i) Induction furnace slag can be used as partial cement replacement in concrete.

(ii) Concrete samples containing $15 \%$ and $20 \%$ slag content showed almost identical results in compression, flexure and splitting tensile strength for all three curing mediums

(iii) Concrete samples containing $15 \%$ or more slag are almost completely immune to sulphate and chloride damage.

(iv) $20 \%$ slag replacement samples lost an average $20 \%$ compressive strength at 28 days, $39 \%$ flexural strength at 56 days and $47.5 \%$ splitting tensile strength at 56 days in sulphate and chloride mediums in comparison to control samples cured in water medium. 
(v) $\quad 15 \%$ slag replacement samples only lost an average $10 \%$ compressive strength at 28 days, $31 \%$ flexural strength at 56 days and $27.5 \%$ splitting tensile strength at 56 days in sulphate and chloride mediums in comparison to control samples cured in water medium.

(vi) Considering the losses in strength with every increase in slag percentage and chloridesulphate immunity in perspective, $15 \%$ slag replacement is deemed as the optimum partial replacement value.

\section{BENEFITS}

The benefits of using optimum replacement (15\% slag) in concrete are listed below:

(i) Cost per meter cube of concrete will be reduced by 503 PKR or $13.4 \%$.

(ii) Carbon dioxide $\left(\mathrm{CO}_{2}\right)$ emissions will be reduced by $5.27 \%$.

(iii) Concrete will be immune against sulphate and chloride damage.

(iv) $\quad 31 \mathrm{~mm}$ slump increase will improve efficient mixing and workability of concrete mix.

(v) $1.64 \%$ increase in dry density will improve structural stability, acoustic and thermal insulation and water tightness of concrete.

(vi) Improved workability, chemical damage immunity and better water tightness will also help in reducing repair and maintenance costs.

\section{ACKNOWLEDGMENT}

The authors wish to express their gratitude towards Prof. Dr. Zulfiqar Ali Khan, Department of Civil Engineering, The University of Lahore, Lahore, Pakistan, for his valuable support and facilitation for culminating this research in his department.

\section{REFERENCES}

[1] Hamdy K.S., Ahmed, S.E., and Ahmed, M.W., "Mechanical Properties of Fly Ash Based Geopolymer Concrete with Fulland Partial Cement Replacement", Construction and Building Materials, Volume 126, pp. 56-565, 2016.

[2] Pedro, D., de Brito,J., and Evangelista, L., "Evaluation of High-Performance Concrete with Recycled Aggregates: Use of Densified Silica Fume as Cement Replacement", Construction and Building Materials, Volume 147, pp. 803-814, 2017.

[3] Pešiæ, N., Živanoviæ, S., Garcia, R., and Papastergiou, P., "Mechanical Properties of Concrete Reinforced with Recycled HDPE Plastic Fibres", Construction and Building Materials, Volume 115, pp. 362-370, 2016.

[4] Hendrik, G.O., "Slag-Iron and Steel", US Geological Survey Minerals Yearbook, pp. 70.1-70.6, 2002.

[5] Steel Statistical Yearbook, World Steel Association, pp. 6, 2016.

[6] Some Fact about Pakistan Steel Mill, Pakistan Steel Melters Association, 2017, http://www.steelmelters.com/ pakistan.htm

[7] Steel Mills in Private Sector, Pakistan Steel Melters Association, 2017, http://www.steelmelters.com/ pakistan.htm

[8] Singh, G., Das, S., Ahmed, A.A., Saha, S., and Karmakar, S., "Study of Granulated Blast Furnace Slag as Fine Aggregates in Concrete for Sustainable Infrastructure", Procedia - Social and Behavioral Sciences, Volume 195, pp. 2272-2279, 2015. 
[9] Ozbakkaloglu, T., Gu, L., and Pour, A.F., "Normaland High-Strength Concretes Incorporating Air-Cooled Blast Furnace Slag Coarse Aggregates: Effect of Slag Size and Content on the Behavior", Construction and Building Materials, Volume 126,pp. 138-146, 2016.

[10] Aghaeipour, A., and Madhkhan, M., "Effect of Ground Granulated Blast Furnace Slag (GGBFS) on RCCP Durability", Construction and Building Materials, Volume 141, pp. 533-541, 2017.

[11] Khatib, J.M., and Hibbert, J.J., "Selected Engineering Properties of Concrete Incorporating Slag and Metakaolin", Construction and Building Materials, Volume 19, No. 6, pp. 460-472, 2005

[12] Li, H., Wee, T.H., and Wong, S.F., "Early-Age Creep and Shrinkage of Blended Cement Concrete", Materials Journal, Volume 99, No. 1, pp. 3-10, 2002.

[13] Mohammed, T.U., Noor, M.A., Apurbo, S.A., Ahmed, M., Elahi, A., and Mazumder, M.H., "Utilization of Induction Furnace Slag in Concrete as Coarse Aggregate", $1^{\text {st }}$ International Conference on Engineering Research and Practice, Dhaka, Bangladesh, 2017.

[14] ASTM C150/C150M-17, "Standard Specification for Portland Cement", ASTM International, West Conshohocken, PA, 2017.

[15] ASTM C430-17, "Standard Test Method for Fineness of Hydraulic Cement by the 45-mm (No. 325) Sieve", ASTM International, West Conshohocken, PA, 2017.

[16] ASTM C33/C33M-16e1, "Standard Specification for Concrete Aggregates", ASTM International, West Conshohocken, PA, 2016.

[17] ASTM C989/C989M-17, "Standard Specification for Slag Cement for Use in Concrete and Mortars”, ASTM International, West Conshohocken, PA, 2017.

[18] Granulated Blast Furnace Slag, Pakistan Steel, Ministry of Industries \& Production, Government of Pakistan, 2017, http://www.paksteel.com.pk product_gran_slag.html
[19] ACI 211.1-91, "Standard Practice for Selecting Proportions for Normal, Heavyweight, and Mass Concrete", American Concrete Institute Committee, Volume 211, pp. 1-38, 2002.

[20] Jakhrani, A.Q., Samo, S.R., Sobuz, H.R., Uddin, M.A., Ahsan, M.J., and Hasan, M.S., "Assessment of Dissolved Salts Concentration of Seawater in the Vicinity of Karachi”, International Journal of Structural and Civil Engineering, Volume 1, No. 2, pp. 61-69, 2012

ASTM C192/C192M-16, "Standard Practice for Making and Curing Concrete Test Specimens in the Laboratory", ASTM International, West Conshohocken, PA, 2016.

Ramezanianpour, A.A., Atarodi, S., and Sami, M., "Durability of Concretes Containing Ground Granulated Blast Furnace GGBS Against Sulfate Attack",

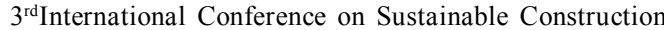
Materials and Technologies, 2017, http:// www.claisse.info/Proceedings.htm

[23] Arivalagn, S., "Sustainable Studies on Concrete with GGBS as a Replacement Material in Cement", Jordan Journal of Civil Engineering, Volume 8,No. No. 3, pp. 263-270, 2014.

[24] ASTM C143/C143M-15a, "Standard Test Method for Slump of Hydraulic-Cement Concrete", ASTM International, West Conshohocken, PA, 2015.

[25] ASTM C39/C39M-18, "Standard Test Method for Compressive Strength of Cylindrical Concrete Specimens", ASTM International, West Conshohocken, PA, 2018.

[26] ASTM C78/C78M-18, "Standard Test Method for Flexural Strength of Concrete (Using Simple Beam with Third-Point Loading)", ASTM International, West Conshohocken, PA, 2018.

[27] Özbay, E., Erdemir, M., and Durmuº, H.I., "Utilization and Efficiency of Ground Granulated Blast Furnace Slag on Concrete Properties - A Review", Construction and Building Materials, Volume 105, pp. 423-434, 2016. 
[28] ASTM C496/C496M-17, "Standard Test Method for Splitting Tensile Strength of Cylindrical Concrete Specimens", ASTM International, West Conshohocken, PA, 2017.
[29] Worrell, E., Price, L., Martin, N., Hendriks, C., and Meida, L.O., "Carbon Dioxide Emissions from The Global Cement Industry", Annual Review of Energy and the Environment, Volume 26, pp. 303-329, 2001. 